\title{
Larysa Wladiczenko, Ukrajina ta Polsza: komparatywnyj analiz widno- sin miż derżawnymi i relihijnymi instytucijami, Kaniw: Wydawnictwo „Rodeń” 2014, ss. 367.
}

Wśród publikacji o charakterze prawno-wyznaniowym, które w ostatnim czasie ukazały się na ukraińskim rynku wydawniczym, na szczególną uwagę zasługuje monografia Larysy Dmitriwnej Wladiczenko pt. Ukrajina ta Polsza:komparatywnyj analiz widnosin miż derżawnymi i relihijnymi instytucijami, Kaniw 2014 (Лариса Владиченко, Украӥна та Польща: компаративний аналіз відносин між державними $i$ релігійними інституціями, Канів: Родень, 2014). Jest to opracowanie obejmujące łącznie 367 stron, na których autorka umieściła wykaz skrótów, przedmowę, cztery merytoryczne rozdziały, wnioski, literaturę oraz dodatki w postaci tablic i grafik.

Wybór tematyki dokonanej przez L. Wladiczenko nie może być przypadkowy, bowiem autorka od dawna w swoich badaniach naukowych zajmuje się problematyką relacji państwowo-kościelnych na Ukrainie, a poza tym w latach 2011-2012 w ramach międzynarodowej współpracy naukowej była także stażystką na Uniwersytecie Jagiellońskim (program im. Lane’a Kirklanda). W efekcie powstało kilkanaście artykułów jej autorstwa dotyczących relacji państwo-kościół na Ukrainie. Dotyczyły one problematyki rejestracji organizacji religijnych, administracji wyznaniowej, restytucji własności kościelnej, oświaty religijnej i duszpasterstwa wojskowego. Autorce udało się także opublikować na Ukrainie kilka publikacji odnoszących się do relacji państwo-kościół w RP i te umieszczone zostały także w wykazie literatury recenzowanej książki stanowiącej efekt szerszego spojrzenia na kwestie komparatystyczne w Polsce i na Ukrainie. 
Trzeba jednak wyraźnie podkreślić, że jest to ujęcie z perspektywy religioznawcy, bowiem L. Wladiczenko to samodzielny pracownik naukowy Katedry Religioznawstwa Narodowego Uniwersytetu im. Tarasa Szewczenki w Kijowie. Zresztą na Ukrainie nie udało się jak dotąd wyodrębnić osobnej gałęzi prawa, np. wyznaniowego (chociażby na wzór polskich rozwiązań), dlatego też problematyka relacji państwowo-kościelnych stała się domeną zainteresowania naukowego, głównie ze strony religioznawców i filozofów a wśród prawników zajmują się tym kanoniści (i to przeważnie znawcy prawa Kościołów wschodnich). Dlatego też należy z uznaniem przyjąć publikację L.Wladiczenko, gdyż do tej pory w literaturze polskiej i ukraińskiej brakowało w miarę kompleksowego opracowania o charakterze porównawczym w zakresie analizy obydwu systemów prawnych regulujących relacje państwo-kościół.

Merytoryczna część książki została podzielona na cztery rozdziały, zróżnicowane objętościowo (odpowiednio: 77, 90, 56 i 45 stron). Najpierw autorka koncentruje uwagę czytelnika na uregulowaniach normatywnych dotyczących relacji państwo-kościół na Ukrainie i w Polsce. W tym miejscu zajmuje się aktualnym stanem prawnym, problemami i kierunkami zmian. W drugim rozdziale znalazły się rozważania dotyczące funkcjonowania administracji wyznaniowej w Polsce i na Ukrainie. Trzeci rozdział to głównie charakterystyka wyznaniowa obu państw, z uwzględnieniem wyznań religijnych o uregulowanej sytuacji prawnej, dane statystyczne dotyczące kościołów oraz struktura organizacyjna poszczególnych związków wyznaniowych. W ostatniej merytorycznej części umieszczono zagadnienia dotyczące mienia należącego do organizacji religijnych, restytucji majątku kościelnego, oświaty religijnej oraz instytucji kapelaństwa wojskowego.

Pierwszy rozdział publikacji to analiza rozwiązań prawnych, najpierw ukraińskich a potem polskich, dotyczących uregulowania wolności sumienia i wyznania. Po pierwsze, L. Wladiczenko wskazuje na konieczność dostosowania ukraińskiego tzw. ustawodawstwa wyznaniowego do standardów określonych w art. 9 EKPC, i tu często odwołuje się do polskich doświadczeń (ustawa o gwarancjach wolności sumienia i wyznania, ustawy indywidualne, konkordat polski). Po wtóre, autorka podkreśla konsekwencje braku jednolitej koncepcji ułożenia relacji państwowo-kościelnych i wciąż zmieniający się układ sił politycznych na przestrzeni ostatnich 20 lat (uzyskanie niezależności, pomarańczowa rewolucja, Majdan) a także lekceważenie opinii Wszechukraińskiej Rady Kościołów i Organiza- 
cji Religijnych (organu doradczego dla prezydenta i rządu w sprawach wyznaniowych). Po trzecie, według autorki państwo nie może się „uporać” ze zwrotem mienia kościelnego znacjonalizowanego jeszcze za czasów sowieckiej Ukrainy. Podejmuje się co prawda działania w tym kierunku, jednak te mają charakter „półśrodków” i to jeszcze naruszających zasadę równouprawnienia kościołów. Po czwarte, rozwiązania wymaga problem opodatkowania organizacji religijnych i ustalenia opłat za korzystanie $\mathrm{z}$ mediów według określonych i niezmieniających się stawek. Po piąte L. Wladiczenko, podkreśla potrzebę ,złagodzenia” państwowej polityki wizowej w stosunku do duchownych - cudzoziemców posługujących religijnie na terytorium Ukrainy (problem dotykający szczególnie księży katolickich pochodzących z Polski). Jeszcze innym problemem wymagającym pilnej zmiany legislacyjnej jest uproszczenie procedury rejestracyjnej w przypadku organizacji religijnych i odejście od konieczności uzyskania podwójnej rejestracji państwowej (raz w rejestrze osób prawnych, drugi raz $\mathrm{w}$ rejestrze organizacji religijnych). Siódmym zadaniem wymagającym interwencji legislacyjnej - według autorki - pozostaje uregulowanie sytuacji prawnej kapelanów wojskowych (ma to szczególne znaczenie w trakcie wojny hybrydowej w Donbasie). Po ósme, należy także zwrócić uwagę na konieczność wprowadzenia zmian umożliwiających nauczanie religii na różnych szczeblach publicznego kształcenia.

W części dotyczącej uwarunkowań prawnych w RP autorka przywołuje polskie, niejako modelowe rozwiązania dotyczące relacji państwowo-kościelnych. W tym miejscu wskazano na znaczenie postanowień polskiej ustawy zasadniczej, obydwu ustaw z 17 maja 1989 r., konkordatu i tzw. indywidualnych ustaw wyznaniowych. Autorka wykorzystuje w tym miejscu polską literaturę przedmiotu i podstawowe opracowania uznanych autorów (M. Pietrzaka, H. Misztala, P. Stanisza, J. Krukowskiego, D. Walencika, P. Boreckiego, T.J. Zielińskiego, A. Mezglewskiego, K. Warchałowskiego, W. Góralskiego, K. Walczuka i innych). Według L. Wladiczenko na poprawę ,jakości" stanowionego prawa regulującego na Ukrainie relacje państwo-kościół mogłyby wpłynąć dwa czynniki, sprawdzone już na gruncie polskim. Po pierwsze, wyodrębnienie osobnej gałęzi prawa wyznaniowego i w konsekwencji uwzględnianie opinii przedstawicieli tego właśnie środowiska naukowego przy tworzeniu odpowiednich aktów prawnych. Po drugie, uzgadnianie zmian legislacyjnych w tym przedmiocie także ze środowiskiem właściwych władz religijnych. 
Drugi rozdział książki L. Wladiczenko stanowi omówienie funkcjonowania administracji wyznaniowej obydwu państw. Warto w tym miejscu zwrócić uwagę na rozwiązania ukraińskie i niezbyt klarowny status centralnego organu administracji wyznaniowej. Nazwa, cele, zadania i struktura tego organu administracji państwowej zmieniała się na przestrzeni lat 1991-2014 aż sześciokrotnie. Poza tym na szczeblu obwodowym i rejonowym często dochodzi do nadużyć urzędniczych i bezprawnego faworyzowania niektórych wspólnot religijnych względem pozostałych. Dotyczy to zwłaszcza sytuacji związanej $\mathrm{z}$ rejestracją organizacji religijnych i stawianiem przeszkód niewynikających wcale $\mathrm{z}$ wymogów formalnych, a będących konsekwencją tzw. polityki regionalnego sprzyjania określonym wyznaniom (np. preferowanie Ukraińskiego Kościoła Greckokatolickiego w zachodniej Ukrainie i jednoczesne dyskryminowanie tam Ukraińskiego Kościoła Prawosławnego Patriarchatu Moskiewskiego). Poza tym autorka szczegółowo analizuje funkcjonowanie poszczególnych organów doradczych (najczęściej rad społecznych) działających przy administracji prezydenckiej i przy ministerstwach, zwłaszcza resortów: kultury, nauki, obrony narodowej, spraw zagranicznych. Poza tym podobne rady utworzono w Radzie Najwyższej Ukrainy, a w strukturach większości organizacji religijnych powołano komórki do spraw współpracy z rządem i samorządem lokalnym. L. Wladiczenko przywołuje aktywność legislacyjną poszczególnych podmiotów państwowych i kościelnych w zakresie uregulowania relacji państwa ukraińskiego z kościołami. Wskazuje jednak na zbyt małą efektywność tych działań i mierną, skuteczność Wszechukraińskiej Rady Kościołów i Organizacji Religijnych jako inicjatora zmian w tym zakresie.

W opozycji do tych doświadczeń autorka podkreśla znaczenie działań polskiego rządu i przedstawicieli głównych wyznań religijnych w Polsce. Wydaje się, że L. Wladiczenko przecenia jednak efekty tej współpracy i zapomina o trudnościach związanych, np. z Funduszem Kościelnym i konsekwencjach jego zlikwidowania. Bez wątpienia autorka ma rację wtedy kiedy podnosi znaczenie układowego uregulowania sytuacji prawnej głównych kościołów w Polsce oraz kiedy zwraca uwagę na konsekwencje prawne wynikające z przyjęcia ustawy o gwarancjach wolności sumienia i wyznania oraz konkordatu (państwo ukraińskie ani wcześniej ZSRR takiej umowy międzynarodowej ze Stolicą Apostolską nigdy nie podpisywało).

Z kolei III rozdział książki L. Wladiczenko stanowi omówienie struktury wspólnot religijnych funkcjonujących w obrocie prawnym w RP i na Ukrainie. W przypadku Polski autorka przytoczyła dane z Ministerstwa 
Administracji i Cyfryzacji, natomiast w przypadku Ukrainy informacje pochodzą z rejestru prowadzonego przez Departament do spraw Religii i Narodowości Ministerstwa Kultury i Sportu Ukrainy (jest to centralny organ administracji wyznaniowej). Autorka swoje rozważania prowadzi pod kątem zorganizowania i struktury poszczególnych wyznań, a także przedstawia dane statystyczne (z 1 stycznia 2014 r.) oraz tendencje rozwoju poszczególnych organizacji religijnych w Polsce i na Ukrainie. Z tych statystyk wynika, że na Ukrainie funkcjonuje 37209 organizacji religijnych, co może wskazywać na olbrzymie dysproporcje w stosunku do liczby związków wyznaniowych zarejestrowanych w porządku prawnym RP. Jednak autorka niedostatecznie wyjaśnia czytelnikowi, że na Ukrainie przyjęto inny niż w Polsce sposób podawania danych statystycznych dotyczący wspólnot religijnych. W rzeczywistości oznacza to, że przywołana liczba prawie 40 tys. odpowiada liczbie zarejestrowanych parafii (lub struktur im odpowiadających), a nie jest to liczba kościołów lub innych związków religijnych w rozumieniu praktyki i prawa polskiego.

Czwarty rozdział opracowania nazwany przez autorkę ,Aktualne zagadnienia relacji państwowo-kościelnych w Polsce i na Ukrainie, charakterystyka i mechanizmy harmonizacji” to według mojej opinii najbardziej wartościowa część publikacji, stąd też najwięcej uwagi poświęcam tym właśnie zagadnieniom. Jednak L. Wladiczenko stosunkowo mało uwagi poświęciła w tym miejscu rozwiązaniom polskim, a główne rozważania oparła na konstrukcjach wykorzystywanych w prawie i praktyce ukraińskiej, co może być faktem wytłumaczalnym (przynajmniej w części). W części „polskiej” większość analiz to uznanie dla polskich doświadczeń po 1989 r. w sprawie uregulowania kwestii zwrotu mienia zabranego kościelnym osobom prawnym w 1950 r. i w latach następnych. Jednak pełna ,gloryfikacja" polskich uzgodnień państwowo-kościelnych w tym zakresie wydaje się być jedynie „ukłonem” wobec polskiego prawa i praktyki ułożenia relacji państwowo-kościelnych lepiej niźli miało to miejsce w przypadku Ukrainy. Zresztą odwołań do „lepszych” niż ukraińskie, bo polskich (także europejskich) doświadczeń jest w tym opracowaniu więcej.

Wracając do treści merytorycznej zawartej w tym rozdziale należy skoncentrować się na uwagach autorki, co do rozwiązań przyjętych na Ukrainie. Trzeba przede wszystkim zwrócić uwagę (tak zresztą czyni L. Wladiczenko) na „balast” w postaci braku przyjęcia koncepcji państwa w przedmiocie uregulowania własności konfesyjnej. W praktyce część organizacji religijnych występuje w charakterze właściciela gruntu 
i budynków o przeznaczeniu sakralnym, część korzysta z tych miejsc na zasadzie odpłatnego użytkowania a jeszcze jedna część dzierżawiąc nie ponosi żadnych opłat za użytkowanie. Powodować to musi konflikty międzykonfesyjne, tak samo jak zróżnicowanie w wysokości tych opłat, uzależnione głównie od uchwał podejmowanych przez odpowiednie organy lokalnej władzy wykonawczej. Poza tym państwo ukraińskie nie respektuje tytułów własności do obiektów kultu religijnego, zwłaszcza tych sprzed 1939 r. i samodzielnie decyduje o przyznaniu prawa do korzystania z tych miejsc według kryterium większościowego (vide kazus lwowskich kościołów rzymskokatolickich przekazanych do korzystania wspólnotom greckokatolickim). Także brakuje nakładów państwowych na niszczejące świątynie różnych wyznań, podczas gdy same wspólnoty religijne nie mają dostatecznych możliwości ich odbudowy. L. Wladiczenko wskazuje na praktykę powierzania przez państwo poszczególnych obiektów sakralnych organizacjom religijnym w celu ich naprawy a potem przekazywaniu takich wyremontowanych budynków podmiotom komercyjnym (s. 260). Trudności wiążą się także z pretendowaniem do jednego obiektu kościelnego przez kilka wspólnot religijnych i z koniecznością sądowego ustalania prawa poszczególnych podmiotów. L. Wladiczenko proponuje w tej sprawie przyjęcie rozwiązania najprostszego z możliwych, czyli zwrotu w naturze majątku lub poprzez rekompensatę pieniężną, jakkolwiek ma świadomość konsekwencji finansowych takiego rozstrzygnięcia. Jednak na Ukrainie wciąż brakuje odpowiednich przepisów w tej sprawie a projekty ustaw normujących kwestie majątkowe blokowane są na różnych etapach procesu legislacyjnego. Autorka słusznie zauważa, że rozwiązanie problemów własnościowych to furtka do kolejnych regulacji relacji państwa ukraińskiego z tamtejszymi organizacjami religijnymi.

Inną kwestią, na którą wyraźnie zwrócono uwagę (s. 263-273) jest sprawa uregulowania możliwości nauki religii w świeckim systemie oświaty (autorka chwali polskie doświadczenia po 1990 r.). Według L. Wladiczenko „religijny komponent w świeckim systemie oświaty Ukrainy ma swoje uzasadnienie ze względu na religijną tradycję i znaczenie moralności chrześcijańskiej w rozwoju młodego pokolenia Ukraińców” (s. 318). Jednak wprowadzenie nauki religii do szkół różnych poziomów nauczania poprzedzone musi być ustaleniem nazwy wykładanego przedmiotu, statusu wykładowców i ich kompetencji oraz zabezpieczeniem metodologicznym całego procesu nauczania. Autorka podkreśla chaos organizacyjny w szkołach, a przede wszystkim brak zdecydowania ukraińskiego 
ustawodawcy, co do wprowadzenia religii do szkół. Jednak L. Wladiczenko przygotowując niniejsze opracowanie nie mogła jeszcze wiedzieć, że 2 czerwca 2015 r. Rada Najwyższa Ukrainy uchwali ustawę „O wprowadzeniu zmian do niektórych przepisów w sprawie zakładania przez organizacje religijne instytucji nauczania" (odtąd kościoły i organizacje religijne działające na podstawie statutów zarejestrowanych na Ukrainie będą mogły zakładać i prowadzić własne placówki oświatowe, np. przedszkola, szkoły ogólnokształcące, technika i szkoły zawodowe oraz wyższe uczelnie).

Kolejna kwestia podjęta w tym rozdziale wydaje się mieć wyjątkowe aktualne znaczenie ze względu na rozwój sytuacji w państwie ukraińskim. W 2014 r. (przynajmniej na początku roku) kiedy L. Wladiczenko zamykała recenzowaną publikację wojna na wschodzie kraju była w początkowej fazie i rozważania autorki miały charakter czysto akademicki. Pod koniec 2014 r. potrzeba wprowadzenia kapelanatu wojskowego (o którym pisze autorka na s. 288-298) wydaje się być inaczej interpretowana i widoczna jest jednoczesna aktywność prawodawcza w tym zakresie, której wcześniej brakowało. Podejmując zagadnienia opieki religijnej L. Wladiczenko zwróciła uwagę na znaczenie tej instytucji w sytuacji konieczności zapewnienia wsparcia duchowego wobec żołnierzy odbywających zasadniczą służbę wojskową (taka formuła wciąż obowiązuje w ukraińskim porząd$\mathrm{ku}$ prawnym). Natomiast w realiach ukraińskich nie przyjęto rozwiązań w postaci ordynariatów polowych, ale większość organizacji religijnych na Ukrainie powołała struktury do spraw duszpasterstwa wojskowego (szerzej w formacjach siłowych) w swoich komórkach organizacyjnych. Także ministerstwo właściwe dla spraw wojskowych już w 1994 r. podjęło działania legislacyjne dotyczące usankcjonowania obecności duchownych w wojsku. Autorka przywołuje projekty ustaw regulujących kapelaństwo wojskowe i wskazuje na wyjątkową aktywność państwa, której brakuje generalnie w sprawie unormowania pozostałych dziedzin relacji władzy państwowej oraz przedstawicieli kościołów i organizacji religijnych.

W recenzowanej publikacji na s. 299-321 L. Wladiczenko umieściła wnioski będące sednem jej rozważań na temat relacji państwo-kościół w Polsce i na Ukrainie. Przede wszystkim wskazano na różnice polegające na tym, że w Polsce wykształciła się gałąź prawa wyznaniowego i w związku z tym doktryna w tym zakresie jest bogatsza, aniżeli dorobek tych dyscyplin naukowych, które badają przedmiotową problematykę z punktu widzenia filozofii czy nauk religioznawczych. Widoczne jest to przez pryzmat przywołanej literatury przedmiotu i widać też wyraźne dysproporcje na 
korzyść polskich opracowań z zakresu prawa. W dalszej części L. Wladiczenko wprost nakreśliła główne problemy związane z regulacją prawną stosunków państwo-kościół (kościoły) na Ukrainie. Zaliczyła do nich przede wszystkim kwestie prawa organizacji religijnych do zakładania szkół, wprowadzenia zinstytucjonalizowanej obecności duchownych w Siłach Zbrojnych Ukrainy, wprowadzenia moratorium na prywatyzację obiektów przeznaczenia religijnego, uproszczenia procedury rejestracji organizacji religijnych oraz przyjęcie koncepcji relacji państwo-kościół uwzględniającej uzasadnione potrzeby organizacji religijnych. Autorka krytycznie odniosła się do funkcjonowania rozbudowanej ale nieefektywnej administracji wyznaniowej wszystkich szczebli organizacyjnych. Tak samo oceniła system podwójnej i przez to długotrwałej procedury rejestracyjnej w stosun$\mathrm{ku}$ do nowych organizacji religijnych i nadmiernej ingerencji państwowej w kwestie wykraczające poza kompetencje władzy państwowej, a należące wyłącznie do właściwości organizacji religijnych i ich władz zwierzchnich.

Uwagi autorki zamieszczone w ostatniej części publikacji zasługują na uwzględnienie ze względu na europejskie aspiracje, przynajmniej części ukraińskiego społeczeństwa i większości przywódców religijnych Ukrainy. Dostosowanie ukraińskich przepisów do standardów prawa i orzecznictwa europejskiego to według autorki opracowania pilna potrzeba chwili. Zresztą już we wprowadzeniu do recenzowanej książki widoczna jest troska L. Wladiczenko w przedmiocie zapewnienia Ukrainie miejsca pośród demokratycznych państw prawnych realizujących właściwie wszystkie jednostkowe i wspólnotowe uprawnienia z zakresu wolności sumienia i religii. Zatroskanie autorki w tym względzie zmaterializowane w formie niniejszej książki, mimo kilku podniesionych przeze mnie uwag, stanowi poważny wkład w rozwój nauki zajmującej się analizowaniem relacji państwo-kościół w ujęciu porównującym rozwiązania normatywne i praktyczne Polski i Ukrainy. Poza tym należy podnieść aspekt oryginalności podejścia autorki do przedstawionej problematyki i wskazać na potrzebę kontynuacji tematu, tym razem w ujęciu przedstawicieli doktryny polskiego prawa wyznaniowego, zwłaszcza uwzględniającej nową rzeczywistość polityczną i prawną po rosyjskiej aneksji Krymu i secesji (?!) Donbasu.

dr Jerzy Nikołajew Zakład Stosunków Międzynarodowych Wyższa Szkoła Stosunków Międzynarodowych i Komunikacji Społecznej $w$ Chetmie 